\title{
Estimation of Superoxide Dismutase, Matrix-metalloprotinase-9, and Interleukin -18 in Patients with Type Two Diabetes Mellitus Shatha R. Moustafa ${ }^{*}, 1$ and Shawn A. Omar* \\ *Academic faculty at College of Pharmacy, Hawler Medical University, Erbil, Iraq. \\ *** Ministry of Heath, Erbil, Iraq.
}

\section{Abstract}

Antioxidant status imbalance and inflammatory process are cooperative events involved in type 2 diabetes mellitus. This study aimed to investigate superoxide dismutase as a potential biomarkers of antioxidant imbalance, matrix-metaloprotinase-9, and interleukin -18 as biomarkers of inflammation in serum and to estimate the effects of other confounding factors gender, age and finally measuring the relation among the interested biomarkers.

This case - control study included 50 patients, and 45 of healthy subjects matched age gender were also enrolled in this study as a control group. The focused parameters were measured using ELISA technique. There was significant reduction in the serum superoxide dismutase level and significant elevation in serum matrix- metaloptotinase-9 and interleukin -18 levels which have been associated with diabetes.

This finding may explain the role of the defect in antioxidants status leading to significant reduction in serum superoxide dismutase levels associated with increased inflammatory process leading to significant elevations of a matrix- metaloptotinase- 9 and interleukin -18 . These parameters added a diagnostic information and evaluated as potential tools for disease risk prediction.

Keywords: Type 2 diabetes mellitus, Superoxide dismutase, Matrix metaloptotinase-9 and Interleukin -18.

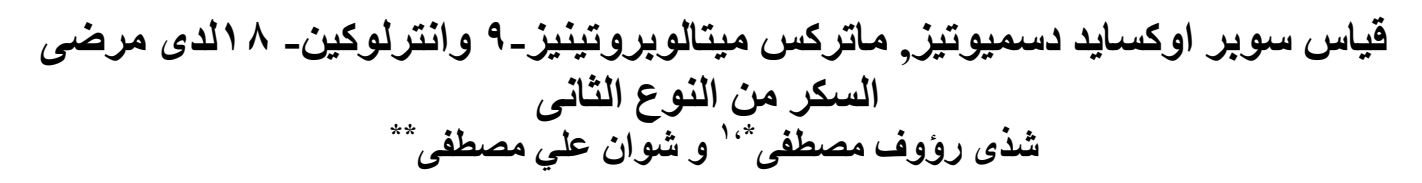

$$
\text { *** وزارة الصيدلة ، جامعة هولير الطبية ، العراق ، اربيل ، العراق . }
$$

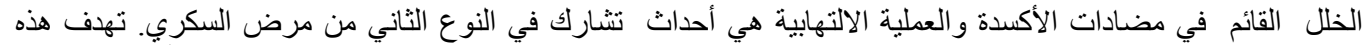

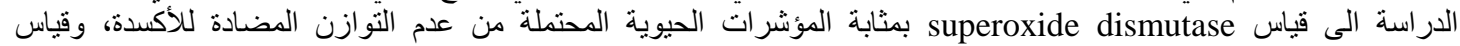

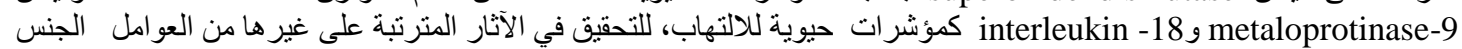

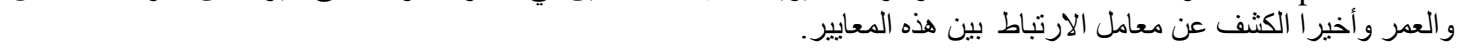

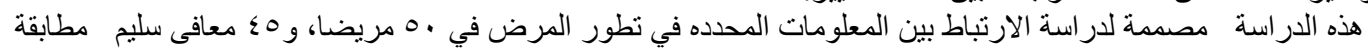

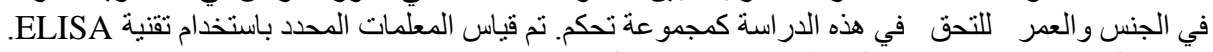

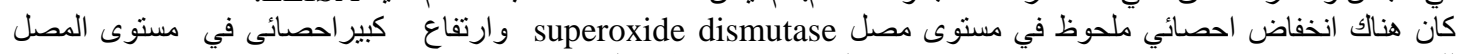

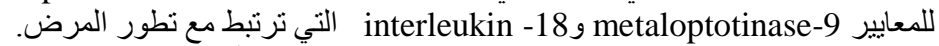

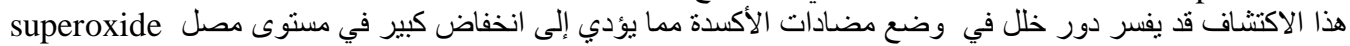
dismutase في الدم وزيادة عملية الالتهاب التي تؤدي إلى ارتفاعات كبيرة في

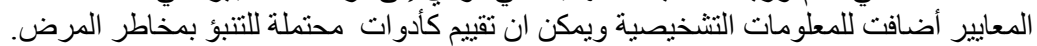

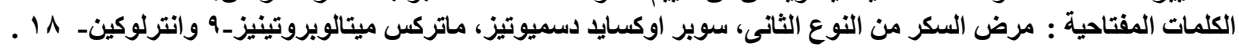

\section{Introduction}

The pathogenesis of type 2 diabetes mellitus is associated with the induction of the OS that is induced by hyperglycemia ${ }^{(1)}$. High blood glucose level induces OS and decrease antioxidant defenses, thus leading to increase free radical (FR) formation so, there was as a significant difference between patients with T2DM and healthy control group concerning the total antioxidant capacity between T2DM patients and healthy control ${ }^{(2)}$. Several studies have reported the lower concentration of antioxidant enzymes in type 2 diabetes such as superoxide dismutase and glutathione peroxidase $^{(3,4)}$. Superoxide dismutase (SOD) CuZnSOD EC 1.15.1.1 is one of the most important intracellular antioxidant enzymes ${ }^{(5)}$.

${ }^{1}$ Corresponding author E-mail: shatha003@yahoo.com

Received: $15 / 10 / 2016$

Accepted: 14/3/2017 
Matrix metalloproteinases (MMPs) are a family of zinc-binding proteolytic enzymes that were remodeling the extracellular matrix and then as the response of the inflammatory process pathologically attack the substrates (6). Increased activity of MMPs has been reported in numerous disease processes. Hyperglycemia and DM enhance expression and activity of MMPs, MMP-9 has been investigated to be increased as a result of the stress hyperglycemia ${ }^{(7)}$.

Interleukin -18 (IL-18) is a proinflammatory cytokine with multiple biologic functions. Elevated levels of IL-18 has been found in the serum of patients with T2DM ${ }^{(8)}$. From these information, it has been found that immunological and inflammatory processes have an important roles in an initiation and progression of the disease as the same time it was known that inflammatory process plays in etiologic and pathogenic mechanisms for T2DM.

Because of impaired glucose metabolism leads to OS and there is an interrelationship between OS and inflammatory process so, this study was aimed to determine the association of the change in serum levels of SOD, MMP-9, and IL-18 with T2DM development and to assess other confounding risk factors age, gender and finally detect the relation between these studied parameters.

\section{Patients and Methods}

This case-control study was designed to examine the associations between the selected parameters with in T2DM patients that was performed at Hawler Medical University, College of Pharmacy on 50 patients of both genders who were randomly selected and newly diagnosed by specialist using clinical examination and confirmed by laboratory tests at diabetic center (Al-Shahida Layla Qassim) and after exclusion of other diseases by clinical history, laboratory investigations and clinical examination. In addition to 45 age gender matched subjects have been also enrolled in this study as a control group who were also randomly selected. All participants completed the baseline questionnaire concerning several risk factors. This study has been done during the period between October 2013 to December 2014. The control group was confirmed to be healthy by clinical, biochemical and hematological examinations. All clinicopathological data of the patients have been collected from the clinical files.

During the period of this study, the patients and the control groups were not taken anti-inflammatory drugs and antioxidants as dietary supplements. All procedures were in accordance by the established ethical standards. The protocol of this study has been approved by Ethics Committee of Medical Research at College of Pharmacy / Hawler Medical University. Oral consents have been taken from all the participants before starting the study.

Sample collection

Ten $\mathrm{ml}$ of the fasting blood samples have been collected and left for 30 minutes for coagulation purposes and then made centrifugation for 15 minutes at 2500$3500 \mathrm{rpm}$. The sera of the participants have been separated and divided into several parts and put them into several plastic plain tubes for the biochemical analysis. The sera of the patients and control groups have been stored at $\left(-80 \mathrm{C}^{\circ}\right)$ at Medical Research Center /Hawler Medical University till the day of the analysis. The sera have been prepared for measurement by thawing the frozen sera at room temperature. The studied parameters have been estimated using enzyme - linked immunosorbent assay (ELISA) technique at Medical Research Center/ Hawler Medical University.

\section{Statistical analysis}

The statistical study has been done using the Statistical Patch for Social Sciences (SPSS vi.18). The results of biochemical tests were expressed as mean \pm standard deviation (SD). Furthermore, student t-test was applied to compare between two means. A (p) value of $\leq 0.05$ was considered as statistical significance. Correlations between laboratory findings and continuous variables were evaluated using linear regression analysis.

\section{Results}

\section{Subjects characteristics}

The clinical characteristics of the patients and control groups have been shown in (Table 1). The patients group has been divided into two groups either as poor control and uncontrolled groups (35 patients with mean age $52.9 \pm 7.8$ and 15 patients with mean age $63.3 \pm 3$ respectively) while the control group has been included 45 healthy adults with mean age was $55.9 \pm 7.5$.

\section{Effect of controlling the disease on the Serum levels of selected parameters}

Serum levels of $\mathrm{HbA}_{1} \mathrm{C} \%$ and glucose were founded to be significantly higher in T2DM patients (uncontrolled group) as compared with poor control and healthy subjects $(\mathrm{p}<0.001)($ Table 1$)$, the serum levels of MMp-9 and IL-18 were increased significantly in uncontrolled group T2DM as compared to poor control and healthy 
individuals $(\mathrm{p}<0.001)$, while the serum level of SOD was decreased significantly in uncontrolled T2DM as compared to poor control and healthy subjects ( $\mathrm{p}<0.001)$.

Table ( 1): The demographic and clinical characteristics of the studied groups

\begin{tabular}{|c|c|c|c|c|c|}
\hline & & $\mathbf{N}$ & Mean & \pm SD & $\mathbf{p}$ \\
\hline \multirow{4}{*}{$\begin{array}{l}\text { Age } \\
\text { (Years) }\end{array}$} & No DM & 45 & 55.933 & 7.500 & \multirow[t]{4}{*}{$<0.001$} \\
\hline & Poor control & 35 & 52.857 & 7.845 & \\
\hline & Un-control & 15 & 63.267 & 3.011 & \\
\hline & Total & 95 & 55.958 & 7.877 & \\
\hline \multirow{4}{*}{$\begin{array}{l}\text { Weight } \\
(\mathrm{Kg})\end{array}$} & No DM & 45 & 74.222 & 4.188 & \multirow[t]{4}{*}{.168} \\
\hline & Poor control & 35 & 73.943 & 7.372 & \\
\hline & Un-control & 15 & 70.400 & 11.319 & \\
\hline & Total & 95 & 73.516 & 6.986 & \\
\hline \multirow[t]{4}{*}{$\mathrm{HbA}_{1} \mathrm{C} \%$} & No DM & 45 & 5.281 & .183 & \multirow[t]{4}{*}{$<0.001$} \\
\hline & Poor control & 35 & 8.386 & .323 & \\
\hline & Un-control & 15 & 10.487 & 1.499 & \\
\hline & Total & 95 & 7.247 & 2.097 & \\
\hline \multirow{4}{*}{$\begin{array}{l}\mathrm{FBG} \\
\mathrm{mg} / \mathrm{dl}\end{array}$} & No DM & 45 & 92.311 & 6.338 & \multirow[t]{4}{*}{$<0.001$} \\
\hline & Poor control & 35 & 231.486 & 26.983 & \\
\hline & Un- control & 15 & 297.133 & 42.963 & \\
\hline & Total & 95 & 175.926 & 86.010 & \\
\hline \multirow{4}{*}{$\begin{array}{l}\text { MMP-9 } \\
\mathrm{ng} / \mathrm{ml}\end{array}$} & No DM & 45 & 1.506 & .945 & \multirow[t]{4}{*}{$<0.001$} \\
\hline & Poor control & 35 & 1.804 & .943 & \\
\hline & Un-control & 15 & 4.563 & 1.669 & \\
\hline & Total & 95 & 2.098 & 1.524 & \\
\hline \multirow{4}{*}{$\begin{array}{l}\text { IL-18 } \\
\mathrm{pg} / \mathrm{ml}\end{array}$} & No DM & 45 & 48.400 & 26.375 & \multirow[t]{4}{*}{$<0.001$} \\
\hline & Poor control & 35 & 84.240 & 17.581 & \\
\hline & Un-control & 15 & 116.760 & 6.603 & \\
\hline & Total & 95 & 72.398 & 32.953 & \\
\hline \multirow{4}{*}{$\begin{array}{l}\text { SOD } \\
u g / m l\end{array}$} & No DM & 45 & 501.447 & 162.781 & \multirow[t]{4}{*}{$<0.001$} \\
\hline & Poor control & 35 & 357.320 & 43.149 & \\
\hline & Un-control & 15 & 171.867 & 51.409 & \\
\hline & Total & 95 & 396.308 & 165.428 & \\
\hline
\end{tabular}

$p<0.05$

Effect of the type 2 diabetes mellitus on the serum levels of selected parameters:

The statistical study has been exhibited that the serum levels of $\mathrm{HbA}_{1} \mathrm{C} \%$,glucose, MMp-9 and IL-18 were significantly increased in patients with T2DM as compared with the control group $\mathrm{p}<0.001$, while the serum level of SOD was significantly decreased in patients with T2DM as compared with the control group $\mathrm{p}<0.001$ (Table 2 ). 
Table ( 2): Comparison between the studied groups regarding the focused parameters

\begin{tabular}{|c|c|c|c|c|c|c|}
\hline & Group & $\mathbf{N}$ & Mean & \pm SD & SE & $\mathbf{p}$ \\
\hline \multirow{2}{*}{$\begin{array}{c}\text { Age } \\
\text { years }\end{array}$} & patients & 50 & 55.980 & 8.277 & 1.171 & \multirow[t]{2}{*}{.977} \\
\hline & Control & 45 & 55.933 & 7.500 & 1.118 & \\
\hline \multirow{2}{*}{$\begin{array}{c}\text { Weight } \\
\text { kg }\end{array}$} & patients & 50 & 72.880 & 8.775 & 1.241 & \multirow[t]{2}{*}{.337} \\
\hline & Control & 45 & 74.222 & 4.188 & .624 & \\
\hline \multirow[t]{2}{*}{$\mathbf{H b A}_{1} \mathbf{C} \%$} & patients & 50 & 9.016 & 1.288 & .182 & \multirow[t]{2}{*}{$<0.001$} \\
\hline & Control & 45 & 5.281 & .183 & .027 & \\
\hline \multirow{2}{*}{$\begin{array}{l}\text { FBG } \\
\text { Mg/dl }\end{array}$} & patients & 50 & 251.180 & 44.227 & 6.255 & \multirow[t]{2}{*}{$<0.001$} \\
\hline & Control & 45 & 92.311 & 6.338 & .945 & \\
\hline \multirow{2}{*}{$\begin{array}{c}\text { MMP-9 } \\
\text { ng/ml }\end{array}$} & patients & 50 & 2.632 & 1.745 & .247 & \multirow[t]{2}{*}{$<0.001$} \\
\hline & Control & 45 & 1.506 & .945 & .141 & \\
\hline \multirow{2}{*}{$\begin{array}{l}\text { IL-18 } \\
\text { pg/ml }\end{array}$} & patients & 50 & 93.996 & 21.297 & 3.012 & \multirow[t]{2}{*}{$<0.001$} \\
\hline & Control & 45 & 48.400 & 26.375 & 3.932 & \\
\hline \multirow{2}{*}{$\begin{array}{c}\text { SOD } \\
\text { ug }\end{array}$} & patients & 50 & 301.684 & 97.041 & 13.724 & \multirow[t]{2}{*}{$<0.001$} \\
\hline & Control & 45 & 501.447 & 162.781 & 24.266 & \\
\hline
\end{tabular}

$\mathrm{p}<0.05$

Gender effect

Concerning MMP-9, there was a significant difference between males and females in patients group $\mathrm{p}=0.049$ (Table3). Regarding SOD and IL-18, there were no significant differences between men and women in patients group $\mathrm{p}>0.05$. While,

in both studied groups, concerning MMP-9, there was a significant difference between males and females $\mathrm{p}=0.049$ as well as there were no significant differences between men and women regarding $\mathrm{HbA}_{1} \mathrm{C}$, glucose, SOD and IL-18 p > 0.05 (Table 4).

Table (3): Comparison between males and females concerning the focused parametersin patient group

\begin{tabular}{|c|c|c|c|c|c|}
\hline & Sex & $\mathbf{N}$ & Mean & \pm SD & $\mathbf{p}$ \\
\hline \multirow{2}{*}{$\begin{array}{l}\text { MMP-9 } \\
\text { ng/ml }\end{array}$} & Men & 25 & 2.512 & 1.840 & \multirow[t]{2}{*}{.049} \\
\hline & Women & 25 & 1.861 & 1.070 & \\
\hline \multirow{2}{*}{$\begin{array}{l}\mathrm{IL}-18 \\
\mathrm{pg} / \mathrm{ml}\end{array}$} & Men & 25 & 70.906 & 36.060 & \multirow[t]{2}{*}{.665} \\
\hline & Women & 25 & 73.858 & 29.912 & \\
\hline \multirow{2}{*}{$\begin{array}{l}\text { SOD } \\
u g / m l\end{array}$} & Men & 25 & 367.226 & 128.068 & \multirow[t]{2}{*}{.090} \\
\hline & Women & 25 & 424.785 & 192.370 & \\
\hline
\end{tabular}

$\mathrm{p}<0.05$

Table (4): Comparison between males and females concerning the focused parameters in both groups

\begin{tabular}{|c|c|c|c|c|c|}
\hline & $\overline{\text { Sex }}$ & $\overline{\mathbf{N}}$ & Mean & SD & $\mathbf{P}$ \\
\hline \multirow{2}{*}{$\begin{array}{l}\text { Age } \\
\text { Years }\end{array}$} & Men & 47 & 55.936 & 8.641 & \multirow[t]{2}{*}{0.979} \\
\hline & Women & 48 & 55.979 & 7.141 & \\
\hline \multirow{2}{*}{$\begin{array}{l}\text { Weight } \\
\mathrm{Kg}\end{array}$} & Men & 47 & 74.213 & 6.504 & \multirow[t]{2}{*}{0.339} \\
\hline & Women & 48 & 72.833 & 7.433 & \\
\hline \multirow[t]{2}{*}{$\mathrm{HbA} 1 \mathrm{C} \%$} & Men & 47 & 7.359 & 2.348 & \multirow[t]{2}{*}{0.609} \\
\hline & Female & 48 & 7.137 & 1.837 & \\
\hline \multirow{2}{*}{$\begin{array}{l}\mathrm{FBG} \\
\mathrm{mg} / \mathrm{dl}\end{array}$} & Men & 47 & 176.532 & 90.680 & \multirow[t]{2}{*}{0.946} \\
\hline & Women & 48 & 175.333 & 82.139 & \\
\hline \multirow{2}{*}{$\begin{array}{l}\text { MMP-9 } \\
\mathrm{ng} / \mathrm{ml}\end{array}$} & Male & 47 & 2.409 & 1.840 & \multirow[t]{2}{*}{0.049} \\
\hline & Women & 48 & 1.794 & 1.070 & \\
\hline \multirow{2}{*}{$\begin{array}{l}\text { IL-18 } \\
\mathrm{pg} / \mathrm{ml}\end{array}$} & Men & 47 & 70.906 & 36.060 & \multirow[t]{2}{*}{0.665} \\
\hline & Women & 48 & 73.858 & 29.912 & \\
\hline \multirow{2}{*}{$\begin{array}{l}\text { SOD } \\
\mathrm{ug} / \mathrm{ml}\end{array}$} & Men & 47 & 367.226 & 128.068 & \multirow[t]{2}{*}{0.090} \\
\hline & Women & 48 & 424.785 & 192.370 & \\
\hline
\end{tabular}

$\mathrm{p}<0.005$ 


\section{Age effect}

There was a significant negative weak correlation between age and SOD in patients group $(\mathrm{r}=-0.35, \mathrm{p}<0.05)$, as much as the age increase the serum level of SOD decrease, while there were a significant positive weak correlations between age and MMp-9 and IL$18(\mathrm{r}=0.28, \mathrm{p}<0.05)(\mathrm{r}=0.26, \mathrm{p}<0.05)$ respectively (Table 5).

Table ( 5): The correlation between the age with SOD, MMP-9 and IL-18 in diabetic patients

\begin{tabular}{|l|l|l|l|l||}
\hline $\begin{array}{l}\mathbf{X} \\
\text { variable }\end{array}$ & $\begin{array}{l}\text { Y } \\
\text { variable }\end{array}$ & $\mathbf{R}$ & $\begin{array}{l}\mathbf{P} \\
\text { value }\end{array}$ & $\mathbf{N}$ \\
\hline Age & SOD & -0.35 & $<0.05$ & 50 \\
\hline Age & MMP-9 & 0.28 & $<0.05$ & 50 \\
\hline Age & IL-18 & 0.26 & $<0.05$ & 50 \\
\hline
\end{tabular}

Correlation coefficient

Correlation coefficient between $\mathrm{HbA}_{I} \mathrm{C}$ and studied parameters

There was a strong significant inverse correlation between $\mathrm{HbA}_{1} \mathrm{C}$ and SOD $(\mathrm{p}<0.001)$ as much as $\mathrm{HbA}_{1} \mathrm{C}$ increase SOD decrease which showed more OS ( $\mathrm{r}$ $=-0.88, \quad \mathrm{p}<0.001)$. Moreover, there was a strong significant positive correlation between $\mathrm{HbA}_{1} \mathrm{C}$ and MMP-9 ( $\left.\mathrm{r}=0.76, \mathrm{p}<0.001\right)$, as much as $\mathrm{HbA}_{1} \mathrm{C}$ increased the serum level of MMP-9 increased. In addition, there was a strong significant positive correlation between $\mathrm{HbA}_{1} \mathrm{C}$ and IL-18 ( $\left.\mathrm{r}=0.76, \mathrm{p}<0.001\right)$, as much as $\mathrm{HbA}_{1} \mathrm{C}$ increased the serum level of IL-18 increased (Table 6).

Table (6): The relation between $\mathrm{HbA}_{1} \mathrm{C}$ with SOD, MMP-9, IL-18 in diabetic patients

\begin{tabular}{||l|l|l|l|l||}
\hline $\begin{array}{l}\text { Y } \\
\text { variable }\end{array}$ & $\begin{array}{l}\mathbf{X} \\
\text { variable }\end{array}$ & $\mathbf{R}$ & $\mathbf{P}$ & $\mathbf{N}$ \\
\hline $\mathrm{HbA}_{1} \mathrm{C}$ & SOD & - & $<0.001$ & 50 \\
& & 0.88 & & \\
\hline $\mathrm{HbA}_{1} \mathrm{C}$ & MMP-9 & 0.76 & $<0.001$ & 50 \\
\hline $\mathrm{HbA}_{1} \mathrm{C}$ & IL-18 & 0.76 & $<0.001$ & 50 \\
\hline
\end{tabular}

Correlation coefficient between studied parameters in patients group.

In patients group, there were a negative strong correlations between SOD with IL-18 and MMp-9 ( $\mathrm{r}=-0.89, \mathrm{p}<0.001 ; \mathrm{r}=-0.7, \mathrm{p}$ $<0.001)$ respectively. In addition, there was a positive strong correlations between MMP-9 with IL-18 ( $\mathrm{r}=0.7, \mathrm{p}<0.001)$ (Table 7).
Table (7): Correlations between the focused parameters in the patients group

\begin{tabular}{||l|l|l|l|l|}
\hline \hline $\begin{array}{c}\mathbf{X} \\
\text { variable }\end{array}$ & \multicolumn{1}{c|}{$\begin{array}{c}\text { Y } \\
\text { variable }\end{array}$} & $\mathbf{R}$ & $\begin{array}{l}\text { P } \\
\text { value }\end{array}$ & N \\
\hline SOD & IL-18 & -0.89 & $<0.001$ & 50 \\
\hline SOD & MMP-9 & -0.70 & $<0.001$ & 50 \\
\hline IL-18 & MMP-9 & 0.70 & $<0.001$ & 50 \\
\hline
\end{tabular}

\section{Discussion}

T2DM and its complications are becoming one of the most important health problems in Erbil population. Therefore, it is necessary to confirm the involvement of novel pathogenic way to provide a good chance for early diagnosis and therapy. The current results has exhibited that antioxidant enzyme SOD and inflammatory markers MMP-9 and IL-18 are useful biomarkers for differentiating diabetic patients from healthy individuals. The results were in harmony with the hypothesis of the current study that, there were a statistical relationship between the significant decreased in the serum level of SOD and significant elevation of the serum levels of MMP-9 and IL-18 with development of T2DM. This study has been detected the existence of inflammation with reduction of antioxidant status in patients with T2DM. The results also suggested that the reduction of the serum antioxidant level may be presented consequence as increased OS associated with T2DM.

\section{Effect of controlling the disease on the serum levels of selected parameters}

In uncontrolled patients with T2DM, the serum levels of $\mathrm{HbA}_{1} \mathrm{C} \%$, glucose, MMP-9 and IL-18 were significantly increased as compared with poor control and healthy individuals (Table 1), while there was a significantly decreased in the serum SOD level in uncontrolled patients with T2DM as compared with poor control and healthy individuals (Table 1). The result of SOD has been exhibited that, OS is severe through uncontrolled stage of the disease which was concordant with the previous findings ${ }^{(4)}$.

\section{Effect of the Type 2 diabetes mellitus on the serum levels of selected parameters}

The statistical study has been revealed that there was a significant decrease in the serum SOD level in patients with T2DM as compared with the control group (Table 2).

It has been published (3) that hyperglycemia may interfere with the defensive mechanism antioxidant enzymes which induces the generation of free radicals (FRs). The statistical decrease in the serum SOD level which was significantly related with 
the development of T2DM and might be used as a necessary biomarker for diagnosis T2DM.

The current study has been shown an elevated OS as a consequence of overproduction of FRs in patients with T2DM concomitant with the significant decreased in antioxidant enzymes such as SOD which might be associated to the etiology of T2DM and has been used as an important parameters of antioxidant status imbalance and has an significant role in the occurrence of T2DM. The result of the present study was concordant with the previous findings ${ }^{(3,4)}$.

The explanation for the reduction of antioxidant levels in patients with T2DM because of the that antioxidant enzymes may have been diminished as an attempt to counteract the lipid DNA, protein and lipid damage. Moreover, The increased lipid, protein and DNA oxidation may be as a consequence of a weakened antioxidant defensive system ${ }^{(9)}$, SOD is considered the first defensive mechanism line against reactive oxygen species (ROS), and it is thought that the activity of SOD might be affected firstly before other antioxidant enzymes as a result of OS ${ }^{(10)}$. Damaged the activity of SOD is due to over production of superoxide -free radicle in addition to the increased of other ROS and induces lipid peroxidation processes in diabetes (4), moreover, hyperglycemia is associated with loss of $\mathrm{Cu}^{2+}$, which is considered as an important cofactor in SOD activity as well as the activity of SOD is diminished by glycosylation in erythrocytes (10)

The current result indicated that there was a statistical increase in the serum MMP-9 level in patients with T2DM as compared with the control group (Table 2). The result of the present study was consistent with the previous findings ${ }^{(6,8-13)}$. The current study also focused the important role of MMP-9 to predict the development of T2DM, in addition, supported the relation between the statistical increase of the serum MMP-9 level with development of the T2DM.

The explanation for this significant elevation in the serum level of MMP-9 in patients with T2DM was that, high blood glucose level directly or indirectly as a consequence of OS and increase glycosylation of products like lipid or protein might elevate the level of MMP-9 and it's activity in large blood vessels ${ }^{(14)}$, moreover, OS may has a necessary role for the pathogenesis of T2DM as well as MMP-9 is activated as a consequence of the FRs generation, which emphasize that antioxidants have a beneficial effects in T2DM therapy.
It is widely accepted that T2DM is related with low grade chronic inflammation (15). So, increased inflammation is considered as non-dependent risk factor for the development T2DM ${ }^{(16)}$.

This study was designed to detect the IL-18 as an inflammatory diagnostic parameter for T2DM. So, this study emphasized that inflammation is associated with increased level of IL-18 by high blood glucose level. There was a statistical increase in the serum IL-18 level as compared with healthy individuals (Table 2) which was in harmony with the previous studies $(8,17,18$,$) . According to the$ current study that, IL-18 might be associated with the pathogenesis of the T2DM as well as the data supported the role of the inflammatory process in the pathophysiology of T2DM. So, this result supported the findings of the previous researches that T2DM might be considered as a low - grade chronic inflammatory status. So, the high serum IL18 level might expect the development of T2DM and there was a relation between a significant elevation of the serum IL-18 level with the development of T2DM.

\section{Gender-effect}

Concerning MMP-9, there was a significant difference between males and females in patients group (Table3). Regarding SOD and IL-18, there were no significant differences between men and women in patients group (Table3). While, in both studied groups, concerning MMP-9, there was a significant difference between males and females as well as there were no significant differences between men and women regarding $\mathrm{HbA}_{1} \mathrm{C}$, glucose, SOD and IL-18 (Table 4). It has been published (4) and illustrated the association between genders and oxidant / antioxidant state, it has been recognized that, the SOD was increased in non-diabetic healthy men compared with non-diabetic healthy women, while in diabetic state, SOD concentration was slightly reduced but there was no statistical significant difference between diabetic men and diabetic women, so the study ${ }^{(4)}$, has been shown that diabetic patients regardless of the gender, were exposed to an elevated levels of ROS through enhanced lipid peroxidation.

\section{Age - factor}

\section{Effect of aging on glucose serum level in type 2 diabetes mellitus}

T2DM is a common burden in the elderly (19). Aging is associated with alterations in body composition, which has implications for the development of insulin resistance and diabetes. These information supported the result of the current study that 
elderly individuals are at a high risk to develop T2DM. The average age of patients in the

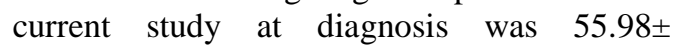
8.277years (Table 2). Moreover, the fining of the current study was in harmony with the result of the previous research (20) which has been reported that, the patients with T2DM group with the average age (60-70 years) their mean blood glucose level was 173.4 \pm 54.2 $\mathrm{mg} / \mathrm{dl}$. Accordingly, there was an association between old age and T2DM.

In addition, other study (21) has been emphasized that an elevated incidence of this disease in elderly subjects might be as result of the variations in the homeostatic pathway that regulates the inflammatory parameters such as C- reactive protein (CRP), IL-6, tumor necrosis factor- $\alpha$ (TNF- $\alpha$ ) which are associated with the chronic low grade inflammation occurs in T2DM.

\section{Effect of aging on studied parameters in type} 2 diabetes mellitus

There was a significant negative weak correlation between age and SOD in patients group, as much as the age increase the serum level of SOD decrease, while there were a significant positive weak correlations between age and MMp-9 and IL-18 (Table 5). Similarly, (4) reported that, SOD lowers in diabetic age group $\geq 50$ years compared with age groups 30-39 and 40-49 years. So, the results of (4) indicated that OS impacts the aging process that may be caused by a number of factors including increased free radical production, decreased antioxidant defense system, or a decreased removal or repair.

\section{Correlation coefficient}

The current study reinforced the possibility that high blood glucose level might be associated with elevated level of MMP-9 and $\mathrm{HbA}_{1} \mathrm{C}$ (Table 6). There was a positive strong statistical relationship between $\mathrm{HbA}_{1} \mathrm{C}$ and MMP-9 when the serum activity of MMP9 was increased the amount of $\mathrm{HbA}_{1} \mathrm{C}$ was also increased. This result was consistent with the finding of the previous research (22). Furthermore, the current result reinforced the possibility that high blood glucose might be associated with reduction in the level of SOD. Table 6 shows, that there was a strong significant negative correlation between $\mathrm{HbA}_{1} \mathrm{C}$ and $\mathrm{SOD}$, as much as $\mathrm{HbA}_{1} \mathrm{C}$ increase SOD decrease which showed more OS, this result was shown that antioxidant status are linked with glycemic control, which was consistent with previous result (23). Indeed, there was a significant interaction between elevated glucose and serum IL-18 level.
Data from the current study reinforced the possibility that high blood glucose level might be associated with elevated concentration of IL-18, the data has been shown a positive strong statistical relation between $\mathrm{HbA}_{1} \mathrm{C}$ and IL-18, when the serum activity of IL-18 was increased the amount of $\mathrm{HbA}_{1} \mathrm{C}$ was also increased. In addition, in patients group, there were a negative strong correlations between SOD with IL-18 and MMp-9. In addition, there was a positive strong correlations between MMP-9 with IL18 (Table7). The current study was the first study in Erbil population that investigated the combined effects of antioxidant status by investigating SOD and inflammation by measuring MMP-9 and IL-18 markers in T2DM risk prediction.

Variations in the serum concentrations of these biomarkers associated with occurrence of T2DM and it is important to supply diagnostic information which might help in the management and therapy of T2DM.

\section{Conclusion}

The results of the current study detected a statistical decrease in the activity of the SOD in patients with T2DM, accordingly, it was concluded that, T2DM is associated with overproduction of FRs as a consequence of hyperglycemia as well as decreased the activity of the antioxidant enzymes like SOD, which emphasized to supply the therapeutics with antioxidant products. Measuring SOD might be used a parameter to regulate the blood glucose level. In addition, the statistical increase in the concentrations of the MMp-9 and Il-18 as an inflammatory markers emphasized the role of inflammatory process in T2DM risk prediction.

\section{Acknowledgments}

Deep thanks and appreciation to Prof. Dr. Namir Al-Tawil for performing the statistical analysis.

\section{References}

1. Román-Pintos LM, Villegas-Rivera G, Rodríguez-Carrizalez AD, Miranda-Díaz AG, Cardona-Muñoz EG. Diabetic Polyneuropathy in Type 2 Diabetes Mellitus: Inflammation, Oxidative Stress, and Mitochondrial Function. J Diabetes Res. 2016; 2016: 3425617.

2. Othman FB, Mohamed HJ, Sirajudeen KN, Noh MF, Rajab NF. The influence of selenium status on body composition, oxidative DNA damage and total antioxidant capacity in newly diagnosed type 2 diabetes mellitus: A case-control study. J Trace Elem Med Biol. 2016; pii: S0946-672X(16)30228-0. 
3. Kasznicki J, Sliwinska A, Kosmalski M, Merecz A, Majsterek I, Drzewoski J. Genetic polymorphisms (Pro197Leu of Gpx1, +35A/C of SOD1, $-262 \mathrm{C} / \mathrm{T}$ of CAT), the level of antioxidant proteins (GPx1, SOD1, CAT) and the risk of distal symmetric polyneuropathy in Polish patients with type 2 diabetes mellitus. Adv Med Sci. 2016; 61(1): 1239.

4. Hisalkar PJ, Payne AB, Fawad MM, Karnik AC. Evaluation of plasma superoxide dismutase and glutathione peroxidase in type 2 diabetic patients. Biology and Medicine 2012; 4 (2): 6572.

5. Gómez-Marcos MA, Blázquez-Medela AM, Gamella-Pozuelo L, RecioRodriguez JI, García-Ortiz L, MartínezSalgado C. Serum Superoxide Dismutase Is Associated with Vascular Structure and Function in Hypertensive and Diabetic Patients. Oxid Med Cell Longev. 2016; 2016: 9124676.

6. Ju C, Ye M, Li F. Plasma Brain Natriuretic Peptide, Endothelin-1, and Matrix Metalloproteinase 9 Expression and Significance in Type 2 Diabetes Mellitus Patients with Ischemic Heart Disease. Med Sci Monit. 2015; 21: 2094-9.

7. Sachwani GR, Jaehne AK, Jayaprakash N, Kuzich M, Onkoba V, Blyden D, Rivers EP. The association between blood glucose levels and matrixmetalloproteinase-9 in early severe sepsis and septic shock. J Inflamm (Lond). 2016; 13: 13.

8. Buraczynska M, Ksiazek K, Zukowski P, Grzebalska A. Interleukin-18 gene polymorphism and risk of CVD in older patients with type 2 diabetes mellitus. Diabetes Res Clin Pract. 2016; 121: 17883.

9. Badjatia N, Satyam A, Singh P, Seth A, Sharma A. Altered antioxidant status and lipid peroxidation in Indian patients with urothelial bladder carcinoma. J Urol Oncol 2009; 28: 1-8.

10. Aldebasi $Y$, Mohieldein A, Almansour Y, Almoteri B. Imbalance of Oxidant/Antioxidant Status and Risk Factors for Saudi Type 2 Diabetic Patients with Retinopathy. Br J Medi Med Res 2011; 1(4):371- 84.

11. Karhaiya Singh, Neeraj K.Agrawal, Sanjeev K.Gupta, Karam Singh. A Functional Single Nucleotide Polymorphism-1562C > Tin the Matrix Metalloproteinase Promotor Is
Associated With Type2 Diabetes on Diabetic Foot Ulcer. Int J Low Extrem Wounds. 2013; 12(3):199- 04.

12. Collin HL, Sorsa $T$, Meurman JH, Niskanen L, Salo T, Rönkä H, Konttinen YT, Koivisto AM, Uusitupa M. Salivary matrix metalloproteinase (MMP-8) levels and gelatinase (MMP-9) activities in patients with type 2 diabetes mellitus. J Periodontal Res. 2000; 35(5): 259-65.

13. Singh K, Agrawal NK, Gupta SK, Mohan G, Chaturvedi S, Singh K. Differential Expression of Matrix Metalloproteinase-9 Gene in Wounds of Type 2 Diabetes Mellitus Cases With Susceptible $-1562 \mathrm{C}>\mathrm{T}$ Genotypes and Wound Severity. Int J Low Extrem Wounds. 2014; 13(2): 94- 02.

14. Chung AW, Hsiang YN, Matzke LA, McManus BM, van Breemen C, Okon EB. Reduced expression of vascular endothelial growth factor paralleled with the increased angiostatin expression resulting from the upregulated activities of matrix metalloproteinase- 2 and -9 in human type 2 diabetic arterial vasculature. Circ Res. 2006; 99:140-8.

15. Pradhan A. Obesity, metabolic syndrome, and type 2 diabetes: inflammatory basis of glucose metabolic disorders. Nutr Rev 2007; 65: 152- 56.

16. Turkmen K. Inflammation, oxidative stress, apoptosis, and autophagy in diabetes mellitus and diabetic kidney disease: the Four Horsemen of the Apocalypse. Int Urol Nephrol. 2016 Dec 29. doi: 10.1007/s11255-016-1488-4. [Epub ahead of print].

17. Zilverschoon GR, Tack CJ, Joosten LA, Kullberg BJ, Meer JW, Netea MG. Interleukin-18 resistance in patients with obesity and type 2 diabetes mellitus. Int J Obes (Lond) 2008; 32:1407- 14.

18. Klimontov VV, Tyan NV, Fazullina ON, Myakina NE, Orlov NB, Konenkov VI1. Acute-phase serum proteins and adipocytokines in women with type 2 diabetes mellitus: Relationships with body composition and blood glucose fluctuations. Ter Arkh. 2016; 88 (10): 35-41.

19. Meneilly GS, Tessier D. Diabetes in elderly adults. J Gerontol A Biol Sci Med Sci 2001; 56: M5-13.

20. Yasmin R, Majeed A, Rashid A, Razak $\mathrm{S}$. The association of age with glycaemic and cholesterol control in patients with type 2 diabetes mellitus. J Pak Med Assoc. 2017; 67(1): 33- 6. 
21. Undurti N. Das. The risk of type 2 diabetes mellitus in those with hypertension._Eur Heart J 2008; 29 (7): 952- 53.

22. Krzysztof C. Lewandowski, Ewa Banach, Małgorzata Bieńkiewicz, and Andrzej Lewiński. Matrix metalloproteinases in type 2 diabetes and non-diabetic controls: effects of short-term and chronic hyperglycaemia. Arch Med Sci. 2011; 7(2): 294-03.

23. Bigagli E, Raimondi L, Mannucci E, Colombi C, Bardini G, RotellaCM and Lodovici M. Lipid and protein oxidation products, antioxidant status and vascular complications in poorly controlled type 2 diabetes. British Journal of Diabetes \& Vascular Disease 2012; 12: 33- 9. 